\title{
COVID-19 e a Ciência
}

Joana Marcela Sales de Lucena

Alexandre Lima de Araújo Ribeiro

O Sars-CoV-2, da família Coronaviridae, é o vírus causador do COVID-19, uma doença que surgiu em Wuhan (China), no final de 2019, e tomou proporções mundiais no início de 2020, quando a OMS declarou uma pandemia'. Até a publicação deste editorial são mais de 2,5 milhões de casos confirmados e cerca de 160 mil mortes em todo o mundo ${ }^{2}$, números que não param de crescer $^{3}$.

Os sintomas recorrentes nos indivíduos que manifestam o COVID-19 são: febre, tosse e falta de ar, a ponto de ocorrer uma grave insuficiência respiratória; esses sintomas aparecerem de 2 a 14 dias após a exposição, podem se agravar e, em alguns casos, culminar em morte 4 O contágio pode ocorrer de diversas formas, como pequenas gotículas presentes no ar e em outros materiais $^{5}$, por isso um dos principais problemas desta pandemia é a fácil contaminação e disseminação do vírus, que pode ocorrer sem a necessidade do contato humano. Adicionalmente, 79\% dos contágios partem de pessoas assintomáticas e $86 \%$ dos casos não chegam a ser diagnosticados ${ }^{6}$.

O Brasil possui uma área territorial de $8.511 .000 \mathrm{~km}^{2}$, com uma população estimada em 210 milhões (2017) ${ }^{7}$, dividida em 26 estados e um Distrito Federal. É o $11^{\circ}$ país do mundo no ranking de casos confirmados, com mais de 2.500 mortes por COVID-19. Mesmo sendo diferente de outros países, devido à sua ampla área territorial $\mathrm{e}$ distribuição de população variada entre os estados, encontra-se em uma situação perto da crítica. A China é muito mais populosa (1 bilhão de pessoas numa área territorial de 9.597 milhões de $\mathrm{km}^{2}$ (2017)) e teve cerca de 4.600 mortes, enquanto a Itália possui 60 milhões de pessoas numa área de $301.338 \mathrm{~km}^{2} \mathrm{e}$ mais de 20 mil mortos. Infelizmente, os Estados Unidos já passa de 45 mil mortos, tendo característica populacional muito parecida com o Brasil, com 327 milhões de pessoas numa área de $9.834 .000 \mathrm{~km}^{2}$.

Embora algumas pessoas insistam em ignorar os riscos $\mathrm{e}$ as 
recomendações dos órgãos de saúde, a difusão de dados científicos tornou-se mais popular nos últimos dias. É importante ressaltar que os estudos sobre o Sars-CoV-2 não são novidade para a ciência mundial e nem para a brasileira. Desde 2003, um Coronavírus (SARS-CoV) foi identificado e associado à doença de Insuficiência Respiratória Aguda (SARS) ${ }^{8}$, só depois, em 2019, surgiu o novo Coronavírus na região de Wuhan, na China, que atualmente é o mais prevalente. Até chegar ao Brasil, o Coronavírus já teve várias mutações, um dos fatores que dificulta o trabalho de pesquisadores de laboratórios brasileiros, engajados no sequenciamento do genoma do Coronavírus para o desenvolvimento de uma vacina ou tratamento. Os pioneiros foram pesquisadores do Instituto Adolfo Lutz, do Instituto de Medicina Tropical da Faculdade de Medicina da USP e da Universidade de Oxford. Eles fazem parte de um projeto chamado Cadde, apoiado pela Fapesp e pelo Medical Research Centers, do Reino Unido, que desenvolve novas técnicas para monitorar epidemias em tempo real e já pulicaram vários estudos científicos explicando a fisiopatologia e outros aspectos do Coronavírus?.
Se por um lado o Brasil tem pesquisadores engajados nessa luta, por outro lado é difícil não lembrar uma característica deste país: o grande índice de desigualdade social e como isso tem sido um fator, por vezes decisivo, nesta pandemia. A COVID-19, inicialmente, atingiu pessoas de classe social mais alta, entretanto, hoje estamos num nível de contaminação comunitária que envolve pessoas de todas as classes sociais e a pergunta que não cala é: como as pessoas de classe social mais baixa enfrentarão essa pandemia e a responsabilidade de evitar o contágio?

$$
\text { Para além das incertezas }
$$
científicas especificamente sobre o Coronavírus, surgem várias outras complicações no sentido acadêmico: $\mathrm{E}$ as pesquisas científicas com seres humanos que estavam em andamento? $\mathrm{E}$ as pesquisas que estavam prestes a iniciar? Devemos interrompê-las? Como retomá-las? Muitos pesquisadores e beneficiados por estas pesquisas tem enfrentado essas incertezas. É natural, afinal, o método científico testar hipóteses controlando variáveis. Mas, no momento, não temos o controle de absolutamente nada.

Interrupções, adiamentos, poucos recursos... muitos estudos sobrevivem dessa forma na ciência 
brasileira. Ausência de financiamento, de recursos materiais fundamentais e, com isso, todo o cronograma de estudos precisa ser adaptado. Longe de esgotar as possibilidades de soluções, desejamos deixar aqui alguns questionamentos: diante de tantas mortes, de tanto esforço mundial, da dedicação de tantos pesquisadores, é tão difícil se adaptar à nova realidade? Como podemos lidar com o novo normal? Não seria a oportunidade de criar um novo método de pesquisa e intervenção?

Para aquelas pesquisas com contato direto com mais de duas pessoas, com intervenções, infelizmente, não parece haver outra alternativa além da interrupção. Para as pesquisas observacionais, existe a alternativa da chamada/gravação de vídeo, telefonema, resposta por e-mail e até uso de correspondência ou entrega de questionários na caixa de correio na residência. Entretanto, nem sempre a tecnologia consegue suprir a necessidade específica de alguns estudos.

Precisamos fazer a seguinte reflexão: Quem tem servido quem? Servimos à ciência ou ela nos serve? Há tanto na ciência para reaprender neste momento. Artigos, livros, podcasts... muito sobre o momento atual e a história que estamos construindo pode ser acessado e conectado ao seu tema de pesquisa e à sua realidade profissional ${ }^{10,11}$. Este é um momento para construir, inovar e pesquisar. A ciência construída neste momento obriga-nos a manter o essencial e passa a ter essa característica fortíssima que deveria ser praxe, mas que apenas na pressão que a crise traz se manifesta: a inovação.

Se puder, fique em casa!

\section{Referências}

1. Director-General's opening remarks at the media briefing on COVID-19 - 11 March 2020. World Health Organization. Disponível em <WHO Director-General's opening remarks at the media briefing on COVID-19 - 11 March 2020>. Acesso em 21 de Abr. de 2020 .

2. Coronavírus disease 2019 (COVID19) situation report - 66. World Health Organization. Disponível em <https://www.who.int/emergencies/diseas es/novel-Coronavírus-2019/situationreports/>. Acesso em 19 de Abril de 2020.

3. Worldometers. Disponível em <https://www.worldometers.info/Corona vírus/>. Acesso em 21 de Abril de 2020. 4. Lauer, S. A., Grantz, K. H., Bi, Q., Jones, F. K., Zheng, Q., Meredith, H. R., ... Lessler, J. (2020). The Incubation Period of Coronavírus Disease 2019 (COVID-19) From Publicly Reported Confirmed Cases: Estimation and Application. Annals of Internal Medicine. https://doi.org/10.7326/M200504

5. Van Doremalen, N., Bushmaker, T., Morris, D. H., Holbrook, M. G., Gamble, A., Williamson, B. N., ... 
Munster, V. J. (2020). Aerosol and Surface Stability of SARS-CoV-2 as Compared with SARS-CoV-1. New England Journal of Medicine, NEJMc2004973. https://doi.org/10.1056/NEJMc2004973 6. Li, R., Pei, S., Chen, B., Song, Y., Zhang, T., Yang, W., \& Shaman, J. (2020). Substantial undocumented infection facilitates the rapid dissemination of novel Coronavírus (SARS-CoV2). Science, 3221(March), eabb3221.

https://doi.org/10.1126/science.abb3221. 7. The World Bank. Disponível em <http://datatopics.worldbank.org/worlddevelopment-indicators/> Acesso em 18 de Abril de 2020.

8. Instituto Brasileiro de Informação em Ciência e Tecnologia - IBICT. Canal Ciência. Disponível em $<$ http://www.canalciencia.ibict.br/cienciaem-sintese1/especial-covid-19/353-novoCoronavírus-origem-e-evolucaobaseadas-em-estudos-filogeneticos>. Acesso em 18 de Abril de 2020.

9. Pesquisadores do Brasil sequenciam genoma do coronavírus que chegou ao país. Correio Braziliense, Brasil. Disponível em

<https://www.correiobraziliense.com.br/a pp/noticia/brasil/2020/02/28/internabrasil,831120/pesquisadores-do-brasilsequenciam-genoma-do-Coronavírusque-chegou-ao.shtml>. Acesso em 19 de Abr. de 2020.

10. ARCA - Repositório Institucional da Fiocruz. Disponível em <https://www.arca.fiocruz.br/simplesearch?location $=\&$ query $=$ COVID\&filter _field_1=dateIssued\&filter_type_1=equal s\&filter_value_1=\%5B2000+TO+2020\% 5 D\&rpp $=10 \&$ sort_by $=$ score\&order $=$ DES C\&etal $=0 \&$ submit_search=Atualizar $>$.

Acesso em 21 de Abril de 2020.

$\begin{array}{lll}\text { 11. Fundação } & \text { Osvaldo Cruz - } \\ \text { FIOCRUZ. } & \text { Disponível } & \text { em }\end{array}$ <https://portal.fiocruz.br/Coronavírus/inf ormacao-em-saude>. Acesso em $21 \mathrm{de}$ Abril de 2020.

\section{Editorial}

Sars-CoV-2, of the Coronaviridae family, is the virus that causes COVID-19, a disease that emerged in Wuhan (China) in late 2019 , and took on worldwide proportions in early 2020, when WHO declared a pandemic ${ }^{1}$. As of the publication of this editorial, there are more than 2.5 million confirmed cases and about 160 thousand deaths worldwide ${ }^{2}$, numbers that continue to grow ${ }^{3}$.

The recurrent symptoms in individuals who manifest COVID-19 are: fever, cough and shortness of breath, to the point of severe respiratory failure; these symptoms appear 2 to 14 days after exposure, they can worsen and, in some cases, culminate in death". Contagion can occur in several ways, such as small droplets present in the air and other materials ${ }^{5}$, so one of the main problems of this pandemic is the easy contamination and spread of the virus, which can occur without the need for human contact. Additionally, $79 \%$ of contagions come from people asymptomatic and $86 \%$ of cases are not diagnosed ${ }^{6}$.

Brazil has a territorial area of $8,511,000$ $\mathrm{km}^{2}$, with an estimated population of 210 million $(2017)^{7}$, divided into 26 states and one Federal District. It is the 11th country in the world in the ranking of confirmed cases, with more than 2,500 deaths due to COVID-19. Even though it is different from other countries, due to its wide territorial area and varied population distribution among the states, it is in a situation close to criticism. China is much more populous (1 billion people in a territorial area of 9,597 million km2 (2017)) and has had about 4,600 deaths, while Italy has 60 million people in an area of $301,338 \mathrm{~km} 2$ and more than 20 thousand deaths. Unfortunately, the United States is already over 45 thousand dead, with a population characteristic very similar to Brazil, with 327 million people in an area of $9,834,000 \mathrm{~km} 2$.

Although some people insist on ignoring health risks and recommendations, the dissemination of scientific data has become more popular in recent days. It is important to note that studies on Sars-CoV-2 are not new to world science or to Brazilian science. Since 2003, a Coronavirus (SARS-CoV) has been identified and associated with Acute Respiratory Insufficiency (SARS) disease ${ }^{8}$, only after, in 2019, did the new Coronavirus appear in the Wuhan region of China, which is currently the most prevalent. Until arriving in Brazil, the Coronavirus already had several mutations, one of the factors that hinders the work of researchers from Brazilian laboratories, engaged 
in sequencing the Coronavirus genome for the development of a vaccine or treatment. The pioneers were researchers at the Adolfo Lutz Institute, the Institute of Tropical Medicine at the USP School of Medicine and the University of Oxford. They are part of a project called Cadde, supported by Fapesp and the Medical Research Centers, from the United Kingdom, which develops new techniques to monitor epidemics in real time and have already published several scientific studies explaining the pathophysiology and other aspects of the Coronavirus".

If, on the one hand, Brazil has researchers engaged in this struggle, on the other hand, it is difficult not to remember one characteristic of this country: the high level of social inequality and how it has been a factor, sometimes decisive, in this pandemic. COVID19 initially reached people of higher social class, however, today we are at a level of community contamination that involves people from all social classes and the question that remains silent is: how will people of lower social class face this pandemic and the responsibility to avoid contagion?

In addition to the scientific uncertainties specifically about the Coronavirus, there are several other complications in the academic sense: What about the scientific research with human beings that was underway? What about the research that was about to start? Should we interrupt them? How to resume them? Many researchers and beneficiaries of these researches have faced these uncertainties. After all, it is natural for the scientific method to test hypotheses by controlling variables. But at the moment, we have no control over anything.

Interruptions, postponements, few resources ... many studies survive in this way in Brazilian science. Absence of funding, of fundamental material resources and, therefore, the entire study schedule needs to be adapted. Far from exhausting the possibilities for solutions, we wish to leave some questions here: in the face of so many deaths, so much world effort, so many researchers dedicating themselves, is it so difficult to adapt to the new reality? How can we deal with the new normal? Wouldn't it be an opportunity to create a new research and intervention method?

For those surveys with direct contact with more than two people, with interventions, unfortunately, there seems to be no alternative but to interrupt. For observational surveys, there is the alternative of video call / recording, phone call, response by e-mail and even use of correspondence or delivery of questionnaires in the mailbox at the residence. However, technology is not always able to meet the specific need for some studies.

We need to make the following reflection: Who has served whom? Do we serve science or does it serve us? There is so much in science to relearn right now. Articles, books, podcasts ... a lot about the current moment and the history we are building can be accessed and connected to your research topic and your professional reality ${ }^{10,11}$. This is a time to build, innovate and research. The science built at this moment obliges us to maintain the essentials and starts to have this very strong characteristic that should be customary, but which only manifests itself in the pressure that the crisis brings: innovation.

If you can, stay home!

\section{Editorial}

Sars-CoV-2, de la familia Coronaviridae, es el virus que causa COVID-19, una enfermedad que surgió en Wuhan (China) a fines de 2019 y adquirió proporciones mundiales a principios de 2020, cuando la OMS declaró una pandemia'. A partir de la publicación de este editorial, hay más de 2.5 millones de casos confirmados y alrededor de 160 mil muertes en todo el mundo ${ }^{2}$, números que continúan creciendo.

Los síntomas recurrentes en individuos que manifiestan COVID-19 son: fiebre, tos y falta de aliento, hasta el punto de insuficiencia respiratoria severa; Estos síntomas aparecen de 2 a 14 días después de la exposición, pueden empeorar y, en algunos casos, culminar en la muerte ${ }^{4}$. El contagio puede ocurrir de varias maneras, como pequeñas gotas presentes en el aire y otros materiales, ${ }^{5}$ por lo que uno de los principales problemas de esta pandemia es la fácil contaminación y propagación del virus, que puede ocurrir sin la necesidad de contacto humano. Además, el $79 \%$ de los contagios provienen de personas asintomático y el $86 \%$ de los casos no son diagnosticados ${ }^{6}$.

Brasil tiene un área territorial de $8,511,000 \mathrm{~km}^{2}$, con una población estimada de 210 millones $(2017)^{7}$, dividida en 26 estados y un Distrito Federal. Es el undécimo país del mundo en el ranking de casos confirmados, con más de 2.500 muertes debido a COVID-19. A pesar de que es diferente de otros países, debido a su amplia área territorial y la distribución de la población variada entre los estados, se encuentra en una situación cercana a las críticas. China es mucho más poblada (mil millones de personas en un área territorial de 9,597 millones de km2 (2017)) y ha tenido alrededor de 4,600 muertes, mientras que Italia tiene 60 millones de personas 
en un área de $301,338 \mathrm{~km}^{2}$ y más de 20 mil muertes. Desafortunadamente, Estados Unidos ya tiene más de 45 mil muertos, con una población muy similar a la de Brasil, con 327 millones de personas en un área de 9,834,000 $\mathrm{km}^{2}$.

Aunque algunas personas insisten en ignorar los riesgos y recomendaciones para la salud, la difusión de datos científicos se ha vuelto más popular en los últimos días. Es importante tener en cuenta que los estudios sobre Sars-CoV2 no son nuevos para la ciencia mundial o la ciencia brasileña. Desde 2003, se identificó un Coronavirus (SARS-CoV) y se asoció con la Enfermedad de Insuficiencia Respiratoria Aguda (SARS) $^{8}$, solo después, en 2019, apareció el nuevo Coronavirus en la región de Wuhan en China, que actualmente es la más prevalente. Hasta su llegada a Brasil, el Coronavirus ya tenía varias mutaciones, uno de los factores que dificulta el trabajo de los investigadores de los laboratorios brasileños, encargados de secuenciar el genoma del Coronavirus para el desarrollo de una vacuna o tratamiento. Los pioneros fueron investigadores del Instituto Adolfo Lutz, el Instituto de Medicina Tropical de la Facultad de Medicina de la USP y la Universidad de Oxford. Forman parte de un proyecto llamado Cadde, respaldado por Fapesp y los Centros de Investigación Médica del Reino Unido, que desarrolla nuevas técnicas para monitorear epidemias en tiempo real y ya ha publicado varios estudios científicos que explican la fisiopatología y otros aspectos del Coronavirus? .

$\mathrm{Si}$, por un lado, Brasil tiene investigadores involucrados en esta lucha, por otro lado, es difícil no recordar una característica de este país: el alto nivel de desigualdad social y cómo eso ha sido un factor, a veces decisivo, en esta pandemia. COVID-19 inicialmente llegó a personas de clase social superior, sin embargo, hoy estamos en un nivel de contaminación comunitaria que involucra a personas de todas las clases sociales y la pregunta que permanece en silencio es: ¿cómo enfrentarán esto las personas de clase social baja? pandemia y la responsabilidad de evitar el contagio?

Además de las incertidumbres científicas específicamente sobre el Coronavirus, hay varias otras complicaciones en el sentido académico: ¿Qué pasa con la investigación científica con seres humanos que estaba en marcha? ¿Qué pasa con la investigación que estaba por comenzar? ¿Deberíamos interrumpirlos? ¿Cómo reanudarlos? Muchos investigadores $\mathrm{y}$ beneficiarios de estas investigaciones han enfrentado estas incertidumbres. Después de todo, es natural que el método científico pruebe hipótesis mediante el control de variables. Pero por el momento, no tenemos control sobre nada.

Interrupciones, aplazamientos, pocos recursos ... muchos estudios sobreviven de esta manera en la ciencia brasileña. Ausencia de financiación, de recursos materiales fundamentales $\mathrm{y}$, por lo tanto, todo el cronograma de estudio debe adaptarse. Lejos de agotar las posibilidades de soluciones, deseamos dejar algunas preguntas aquí: ante tantas muertes, tanto esfuerzo mundial, tantos investigadores dedicados, ¿es tan difícil adaptarse a la nueva realidad? ¿Cómo podemos lidiar con la nueva normalidad? ¿ ¿No sería una oportunidad para crear un nuevo método de investigación e intervención?

Para aquellas encuestas con contacto directo con más de dos personas, con intervenciones, desafortunadamente, no parece haber otra alternativa que interrumpir. Para las encuestas de observación, existe la alternativa de videollamada / grabación, llamada telefónica, respuesta por correo electrónico e incluso uso de correspondencia o entrega de cuestionarios en el buzón de la residencia. Sin embargo, la tecnología no siempre puede satisfacer la necesidad específica de algunos estudios.

Necesitamos hacer la siguiente reflexión: ¿Quién ha servido a quién? ¿Servimos a la ciencia o nos sirve? Hay mucho en ciencia que volver a aprender en este momento. Se puede acceder a artículos, libros, podcasts ... mucho sobre el momento actual y la historia que estamos construyendo y conectar con su tema de investigación y su realidad profesional ${ }^{10,11}$. Este es un momento para construir, innovar e investigar. La ciencia construida en este momento nos obliga a mantener lo esencial y comienza a tener esta característica muy fuerte que debería ser habitual, pero que solo se manifiesta en la presión que trae la crisis: la innovación.

Si puedes, quédate en casa!

Como citar esse editorial / How to cite this editorial:

De Lucena, J. M. S.; Ribeiro, A. L. A. COVID-19 e a Ciência. Arq. Bras. Ed. Fís., Tocantinópolis, v. 2, n. 2, Ago./Dez., p. $09-14,2019$. 